\title{
A Method for Rational Provision of Learning Syllabus
}

\author{
Vida DRĄSUTE் ${ }^{1}$, Sigitas DRĄSUTIS ${ }^{1}$, Dalia BAZIUKË ${ }^{2}$ \\ ${ }^{1}$ Kaunas University of Technology, Faculty of Informatics, Multimedia Engineering Department \\ Studentu str. 50, LT-51368, Kaunas \\ ${ }^{2}$ Klaipeda University, Distance and E-Learning Centre, Computer Science Department \\ Herkaus Manto str. 84, LT-92294, Klaipéda \\ e-mail: \{vida.motekaityte, sigitas.drasutis\}@ktu.lt,dalia.baziuke@ku.lt
}

Received: May 2011

\begin{abstract}
Distance, e-education supported by technological development have enhanced educational processes by combining achievements from various scientific fields. This techno-educational enhancement has happened within the last decade. Virtual learning has grown in popularity as a new way of learning that gives preference to learn in convenient time and places, using specially prepared learning materials. The progression of technological developments implies the rise of user demands. It also aspires to look for flexible, but qualitative, training and learning ways. One of the outcomes is adaptive and intelligent learning environments that show to become a common tool used for virtual learning.

This paper focuses on the key feature elements of adaptive learning environments (ALE), also researching about intelligent agents and their behaviour in ALEs. The method to provide individual learning syllabus according student knowledge in rational way is proposed. It is based on latent semantic indexing algorithm and is featured with an ability to update syllabus according individual learning outcomes of the student. This is yet another tool in a teacher's tool box. The description of results obtained during the exploration of proposed method is presented as well.
\end{abstract}

Keywords: provision of learning syllabus, adaptive learning, intelligent environment, latent semantic indexing.

\section{Introduction}

Properly selected learning syllabus is one of key features to successful learning. It is present in all forms of education, including e-forms. Assorted syllabus becomes crucial for constructing optimal learning path for particular student. Electronic learning syllabus together with e-communication and e-collaboration tools, video conferencing lectures, e-assessment tools seems to be trivial today and is placed in the centre of today's learning environment. Therefore, the increasing importance of e-learning and the integration of information systems in all areas of learning forces teachers to understand and implement information systems and its specialists to start thinking about more efficient and precise mechanisms for such systems' design and implementation, the development of new tools for making e-learning syllabus more accessible and acceptable for users. 
Teaching and learning requires methods and forms of learning syllabus provision which would be as much as possible various and corresponding to different learners' style and knowledge level, therefore in purpose to relieve teaching/learning processes it is important to rationalize the provision of e-learning syllabus.

A virtual learning environment (VLE) is one of the important tool when we speak about development of distance, e-learning, blended learning and it is defined as the webbased application suitable for information exchange between teacher and learner, as well as between learners themselves (Baziukaite, 2007). VLE is commonly known as a specific information system which provides the possibility to create and use different learning scenarios and methods (Kurilovas, 2010).

This article deals with analysis of adaptive learning systems which use agents as intelligent function, and possible solutions for learning syllabus provision, also the method that is based on latent semantic indexing algorithm that enables to provide learning syllabus in rational way, according to student knowledge and got outcomes from self-testing, allows for the teacher to update the curriculum according to students' learning outcomes is provided.

\section{Adaptive Learning Environments}

Historically, assessing the changes which are visible in educational processes development, two significant areas, in particular emerged in the last decade. One of them focuses on teaching the subject, called subject-centered, the other emphasize the development of the personality of the learner, called student-centered. The first area emphasizes the subject matter knowledge, their fundamentality, the ability to apply them. The second axis the curriculum constructed according to a student needs and skills, thus focusing more on the process of learning, teaching and learning environment as itself (Brusilovsky, 2003.). Adaptive learning environments (ALE) that respond to the recent trend - the orientation of the curriculum to the learner, emphasizes his/her self-expression, learning styles recognition, existing and acquired knowledge, more fulfils individual learning needs, materials utilization.

When it is spoken about learning environments, which met the needs of the studentcentered teaching, especially describing intelligence of such learning systems, the ability of being adaptive is often mentioned.

An adaptive system is understood as a system that is able to adapt to changes in the environment in which it is situated. In order to adapt, a system must be able to learn (Baziukaitè, 2007).

The features of ALE which make VLE adaptive are such as (Paramythis and LoidlReisinger, 2003):

- adaptive interaction, which refers to adaptations that take place at the system's interface and are intended to facilitate or support the user's interaction with the system, without, however, modifying in any way the learning "content" itself;

- adaptive course delivery, which constitutes the most common and widely used collection of adaptation techniques applied in learning environments today; 
- content discovery and assembly, which refers to the application of adaptive techniques in the discovery and assembly of learning material / "content" from potentially distributed sources / repositories;

- adaptive collaboration support, which is intended to capture adaptive support in learning processes that involve communication between multiple persons (and, therefore, social interaction), and, potentially, collaboration towards common objectives.

\subsection{Examples of Learning Environments Which Use Intelligent Agents}

This section is intended to discuss four successful projects that took part during the last decade, and, in a rather good manner, describe the coexistence of AI techniques within the web-applications. All these systems address the adaptability and intelligent decision making issue in the VLE. The systems we introduce in this section are web-based systems, where AI techniques are applied mainly for providing adaptive environment for the human user.

ELM-ART II ${ }^{1}$ is an intelligent interactive educational system which supports learning programming in LISP. ELM-ART II provides all learning material online in the form of an adaptive interactive textbook. Using a combination of an overlay model and an episodic student model, ELM-ART II provides adaptive navigation support, course sequencing, individualized diagnosis of student solutions, and example-based problem-solving support. Results of an empirical study show different effects of these techniques on different types of users during the first lessons of the programming course. ELM-ART demonstrates how some interactive and adaptive educational components can be implemented in WWW context and how multiple components can be naturally integrated together in a single system (Weber and Brusilovsky, 2001) This system is the most similar to the vision of the part of the system which is designed using suggested model based on latent semantic indexing algorithm.

NetCoach is an authoring system for adaptive learning courses ${ }^{2}$. It meets the needs to create internet-based adaptive learning courses. It is designed to enable the author to develop adaptive learning courses without programming skills. NetCoach is derived from ELM-ART (Weber and Specht, 1997; Weber and Brusilovsky, 2003). The courses developed using NetCoach are adaptive, interactive, adaptable, and communicative, implements two adaptive navigation techniques: curriculum sequencing (or adaptive navigation support) and adaptive annotation of links (or prerequisite based adaptive annotation).

The VALA ${ }^{3}$ (Virtual Adaptive Learning Architecture) project focuses on developing a learning architecture with user interface adaptability that provides a personalized learning environment, and is a product of the University of Arizona, USA, developed together with other partners including Pima Community College, Sun Microsystems, Silicon Graphics, and Oracle. The interface is supported by a data management system. The elements of

\footnotetext{
${ }^{1}$ http: //art2 .ph-freiburg.de/Lisp-Course.

${ }^{2}$ http: //www. net-coach.de.

${ }^{3}$ http: / /www . vala .arizona.edu .
} 
fuzzy logic are applied in the creation of this assessment driven virtual environment. Two questions guide VALA development: "How is learning different when learning style is taken into account and content is adapted interactively?" and, "What combination of learning path and activities will maximize learning outcomes?" Embedded in each learning module, assessment objects provide ongoing, real-time information about how/what students are learning that can be utilized immediately (Baziukaite, 2007).

Courseware management systems (CMS; for example, WebCT, Blackboard Learning System Vista, Blackboard CourseInfo, IBM Workplace Collaboration Learning System, Moodle, ATutor, etc.) are other type of web applications used in education and are very popular and used by many universities, colleges, schools, other educational institutions in all over the world. These systems are managed mainly by administrators, course providers, tutors, teachers, etc. In the past these systems had only versatility, which is very appreciated by users, and did not have any adaptivity, but in the recent years they are also improved by intelligent components, different standards (for example, SCORM 2004 sequencing and navigation), plug-ins, modules.

In 2007 in Klaipeda University Moodle environment was improved and adaptability was created suggesting the course format SelfEdu for e-learning materials and activities that are placed in a virtual learning environment (VLE). Courses, which are published in SelfEdu way, are dedicated especially for self-education process, which is an important element in lifelong learning phenomenon. This format is based on Moodle ver.1.5 open source VLE and incorporates a set of student tools that in some amount guarantee a successful awareness of presented materials without assistance of a human tutor and a set of teacher tools that help to prepare and publish course materials in a proper way.

The Lesson module in Moodle environment presents a series of HTML pages to the student, who is usually asked to make some sort of choice underneath the content area. The choice will send them to a specific page in the Lesson. In a Lesson page's simplest form, the student can select a continue button at the bottom of the page, which will send them to the next page in the Lesson. There are 2 basic Lesson page types that the student will see: question pages and content pages (formerly called "Branch Tables"). There are also several advanced navigational pages which can meet more specialized needs of the Teacher. The Lesson module was designed to be adaptive and to use a student's choices to create a self directed lesson (Lesson module, 2011).

Therefore adaptability in general is understood as the ability of a system to adjust to the changing environment in which it is situated. According to the analysed definitions for a system to be intelligent, it must have several features: it has to be reactive, proactive and adaptive. Intelligence is understood as a computational task of the system.

In presented adaptive learning systems adaptability is defined by a system's ability to form and, during the learning process, uniformly update the curriculum that satisfies the needs of the learner; intelligence is expressed by the ability to initiate actions and, referring to the learning process, perform decision making processes by applying adopted artificial intelligence (i.e., machine learning) techniques.

The model proposed has four main parts that describe the main functionality of the adaptive and intelligent component (Baziukaité, 2006): 
- setting-up a student knowledge;

- allowing for student to learn according to his/her knowledge and to provide material in rational way;

- controlling a student;

- allowing for teacher to rationalize learning syllabus according to the results of students knowledge.

\section{Intelligent Component Based on Semantic Indexing Algorithm}

The paper proposes an intellectual component, based on a latent semantic indexing algorithm (Deerwester, 1988), implementation can be adapted to any educational course, which consists of a number of subjects and to each subject assigned control questions. Latent semantic indexing is an indexing and retrieval method that uses a mathematical technique called Singular Value Decomposition (SVD) to identify patterns in the relationships between the terms and concepts contained in an unstructured collection of text. LSI is based on the principle that words that are used in the same contexts tend to have similar meanings. A key feature of LSI is its ability to extract the conceptual content of a body of text by establishing associations between those terms that occur in similar contexts (Deerwester, 1988). In our case, this algorithm will be modified (adding 1 in the divisor unit) and applied to rank the students according to results, course topics and questions.

Performing the ranking, for the comparison calculation of arithmetic mean was tested, but it turned out that it does not give objective results when the number of students is small, therefore the divisor in the formula was increased by one. For example: asked question is answered 10 times correctly (the correct answer is marked as 1) and 1 time wrongly (incorrect answer is marked as 0 ), for calculation using a formula for the arithmetic mean counting ( mean $\left._{\text {aritmetic1 }}=10 / 11=0.91\right)$ we get that is worse that mean ${ }_{\text {aritmetic } 1}$ is worse than got mean ${ }_{\text {aritmetic2 } 2}$ counted when the question was answered only once correctly $\left(\right.$ mean $\left._{\text {aritmetic2 }}=1 / 1=1.00\right)$. The problem of wrong results obtained can be solved by adding 1 in divisor (the first case: mean $_{\text {aritmetic1 }}=10 /(11+1)=0.83$, the second case: mean $\left._{\text {aritmetic } 2}=1 /(1+1)=0.5\right)$

From the calculation method of latent semantic indexing algorithm, was used logoritm's function, which reduces fluctuation amplitude of the values of the results.

In the particular case, realization of the intellectual component is provided in Table 1 in which lines are written the students, means of the responses of questions $\left(\mathrm{qmean}_{q n}\right)$ and topics $\left(\operatorname{tmean}_{q}\right.$ ), and in columns are written indexes of the test questions and calculated means of topics $\left(\operatorname{mean}_{q j}\right)$ and averages of all course's responses $\left(\operatorname{mean}_{j}\right)$

When the student starts to learn the topic, each time he/she gets at least 2 or more control questions to which he/she has to answer. The evaluation of the question is $x_{i}$

$$
x_{i}= \begin{cases}0, & \text { question was not offered } \\ 1, & \text { question was not answered } \\ 2, & \text { question was answered }\end{cases}
$$


Table 1

Summary table of question delivery

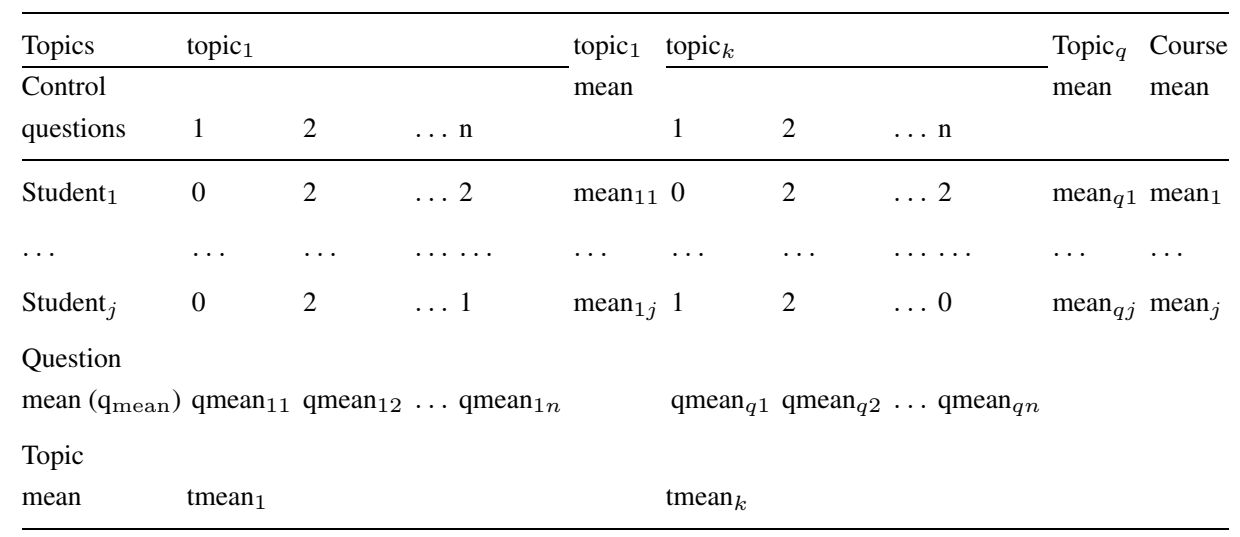

In the initial case, when the number of students who answered to the test questions is equal to 0 , the mean of topic is set $\frac{1}{2}$ of the possible maximum evaluation, and the questions for the students are provided in sequential order, as they are created by the teacher.

The calculation of the average of the student's responses to test questions:

$$
\operatorname{mean}_{j k}=\log \left(1+\frac{\sum_{i=1}^{n} \begin{cases}1, & x_{i}>1 \\
0, & x_{i} \leqslant 1\end{cases} }{\sum_{i=1}^{n}\left\{\begin{array}{ll}
1, & x_{i}>0 \\
0, & x_{i}=0
\end{array}+1\right.}\right) .
$$

When the question is answered by two or more students, then for each test question the average is counted:

$$
\text { qmean }_{k n}=\log \left(1+\frac{\sum_{i=1}^{j} \begin{cases}1, & x_{i}>1 \\
0, & x_{i} \leqslant 1\end{cases} }{\sum_{i=1}^{j}\left\{\begin{array}{ll}
1, & x_{i}>0 \\
0, & x_{i}=0
\end{array}+1\right.}\right) .
$$

The mean of topic:

$$
\operatorname{tmean}_{k}=\log \left(1+\frac{\sum_{i=1}^{m} \begin{cases}1, & x_{i}>1 \\
0, & x_{i} \leqslant 1\end{cases} }{\sum_{i=1}^{m}\left\{\begin{array}{ll}
1, & x_{i}>0 \\
0, & x_{i}=0
\end{array}+1\right.}\right) .
$$

The condition that the topic would be approved (condition to pass the topic):

- The topic is passed (approved that student know it), it means that this topic is not proposed to study, when the average of student's response is greater than or equal 
to the average of the topic and student answered to more than two questions. If this condition is not met and the student was wrong while answered to the question/(-s), the topic is suggested to study.

$$
\begin{cases}\text { approved, } & \text { if } \operatorname{mean}_{q j} \geqslant \operatorname{tmean}_{q}, \text { when } \sum_{i=1, i \geqslant 2}^{n} x_{i} \geqslant 4, \\ \text { suggested to study, } & \text { if } x_{i}=1\end{cases}
$$

Intellectual component, started from the third student, who answers to the questions, can select the test questions in the way that the questions will start from the easiest and will be provided gradually till the most complex.

$$
\operatorname{qmean}_{q i+1} \geqslant \operatorname{mean}_{k i}, \quad \text { when } i \in 1, n \text {. }
$$

The selection of questions in this way allows to rank the questions and starting the topic to provide the easiest, after the topic is learnt, there is possibility to provide more complex questions, also it is the same for the final test.

The condition of selection of final test's questions:

$$
\text { qmean }_{q i} \geqslant \operatorname{mean}_{k i}, \quad \text { when } i \in 1, n \text {. }
$$

The calculation of the mean of the answers to the questions of the topic allows to predict too easy topics/themes and to suggest them for the teacher to remove or merge

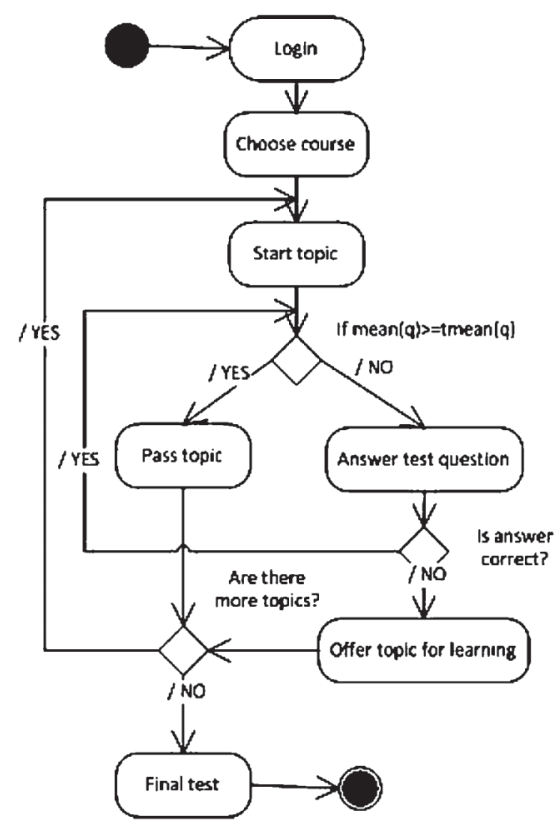

Fig. 1. Student activity diagram. 
with another topic/theme, when:

$$
\lim _{j \rightarrow \infty} \operatorname{tmean}_{q}=\max \left(\operatorname{tmean}_{q}\right) .
$$

In Fig. 1 it is provided activity diagram which shows student's behaviour in the course.

Student log in to the system (VLE or ALE or other, where proposed method is integrated and used), he/she selects the course and starts to learn the topic of the course. Student gets the questions (at least two, in purpose to reduce chances to guess) which are suggested automatically by the system. If student's response/(-s) is greater than or equal to the average of the topic $\left(\operatorname{mean}_{q}>=t \operatorname{mean}_{q}\right)$, the topic is passed (approved that student know it), otherwise student has to read and learn proposed topic and again to answer to the questions he/she gets after reading it. When the student finishes reading all topics of the subject then he/she passes the subject and can go to have final test.

The use and quality of this method was tested with the system, created in Kaunas University of Technology, www. testuok. It. The students from the same study year who are studying the same subject (JAVA programming language) were divided into two groups. For the first group of the students all topics were provided as they are settled in the course (12 topics). And after each topic they had to pass short test, it is to answer to the questions concerned the topic. The results counted by system are shown in Fig. 2. After the teacher analysed the results got from the first group of students, from the answers was visible that topics such as Interface and Packages have very high (almost maximum) and similar answers' coefficient $(0.298$ and 0.273$)$, it means that these topics are not difficult for students and could be merged to one topic. Very similar situation was with the topics Data types and Operations. It was done the same as with the firstly mentioned topics.

The second group learned the topics after they were merged and the results showed that still they are passed well, just a little bit with lower results (but the bias could be also because of the different knowledge of the students, etc.). The topics can be reviewed also when the results are opposite, when most of the students can not pass the topic or the results of the answers are low.

The means of topics of JAVA course

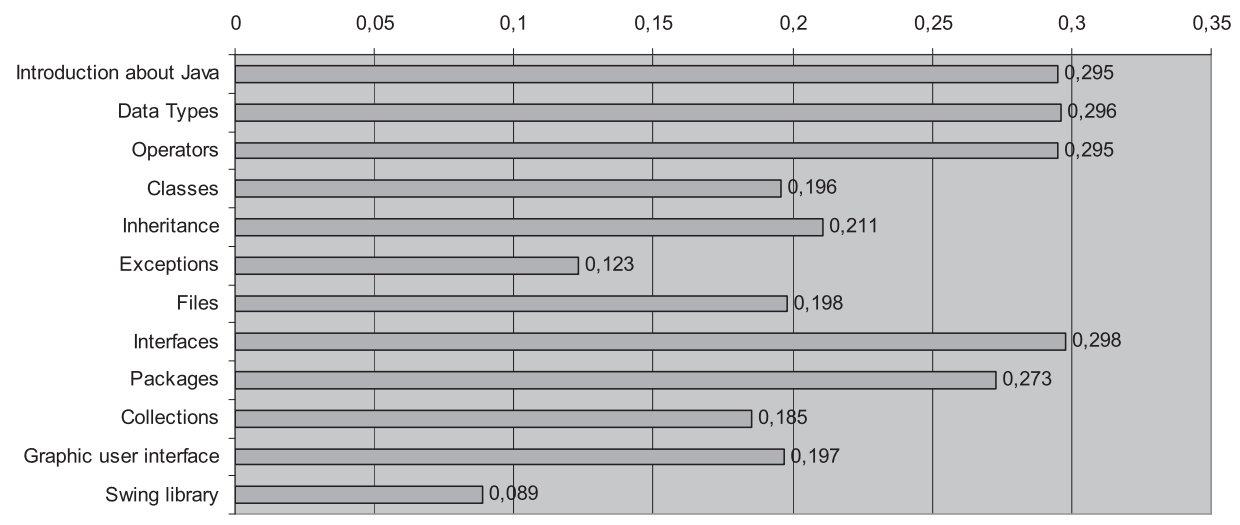

Fig. 2. Results got after testing 1st group. The means of topics of JAVA course. 


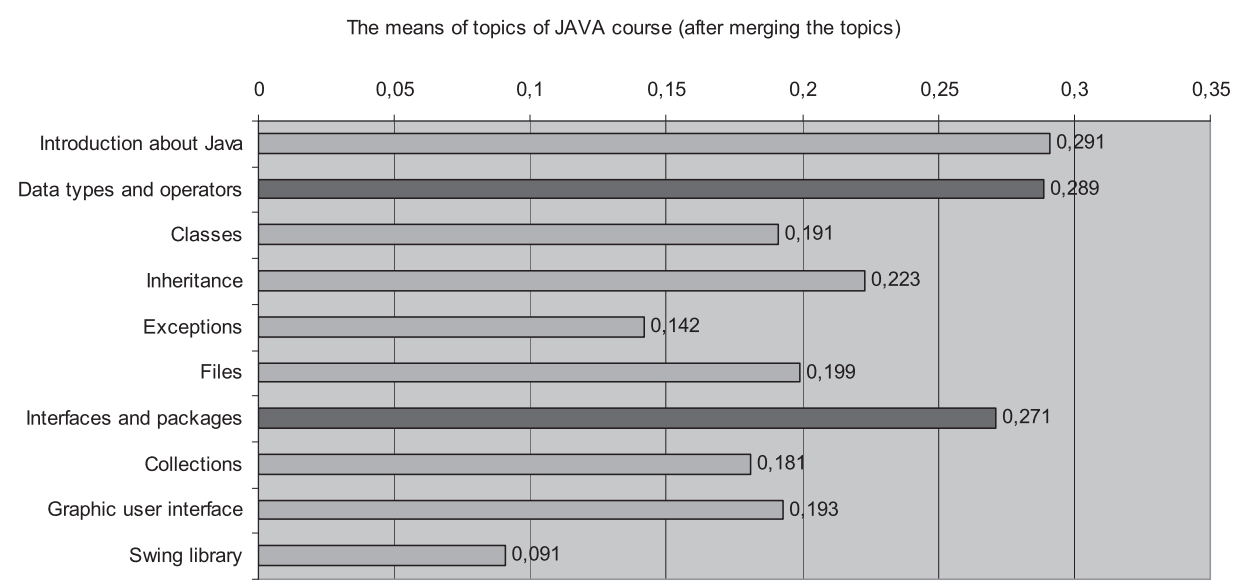

Fig. 3. Results got after testing 2nd group. The means of topics of JAVA course.

\section{Conclusions}

Adaptive learning environments and the usage of agents can be useful in any application area where users have different goals and knowledge. Users with different goals and knowledge may be interested in different pieces of information, methodical material presented in ALE and in this case may use the suggested advantages of the system: can learn according to their knowledge.

In this article, the proposed method which implements the intellectual component and which uses modified latent semantic indexing algorithm, allows to rank students in terms of knowledge, and to provide them with the following questions, also to stimulate their learning progress. The questions in the test are ranked in the order from simpler to more complex. The ranking of the questions allows to identify too complex and too easy questions concerned with particular topics and after review of results the teacher could delete, add, upgrade the questions or to replace the questions with others.

The system which has integrated suggested method may provide for the student only part of the themes where questions were left unanswered. Ranking of the themes allows to identify too complex and too easy topics and offers for the teacher to split or combine the educational material of current themes. Therefore suggested method could be integrated and realized in any adaptive learning environment and it allows rational provision of educational material for the learner.

\section{References}

Baziukaite, D. (2007). Investigation of Q-learning in the context of a virtual learning environment. Informatics in Education, 6(2), 255-268.

Baziukaité, D. (2007). Learner Oriented Methods to Enhance capabilities of Virtual Learning Environment. Doctoral dissertation, Physical Science, Informatics (09P). 
Baziukaité, D. (2006). Approach to an adaptive and intelligent learning environment. In: Elleithy, K., Sobh, T., Mahmood, A., Iskander, M., Karim, M. (Eds.), Advances in Computer, Information, and Systems Sciences, and Engineering, Proceedings of IETA 2005, TeNe 2005 and EIAE 2005. Springer, 399-406.

Brusilovsky, P. (2003). Developing adaptive educational hypermedia systems: From design models to authoring tools. In: Murray, T., Blessing, S. and Ainsworth, S. (Eds.), Authoring Tools for Advanced Technology Learning Environment. Kluwer Academic Publishers, Dordrecht.

Deerwester, S. et al. (1988). Improving information retrieval with latent semantic indexing. In: Proceedings of the 51st Annual Meeting of the American Society for Information Science, Vol. 25, 36-40.

Kurilovas, E. (2010). Improvement of technical quality of virtual learning environments. Informacijos mokslai, 63-72.

Lesson module (2011). http: / / docs . moodle.org/en/Lesson_module.

Paramythis, A., Loidl-Reisinger, S. (2003). Adaptive learning environments and e-learning standards. In: 2nd European Conference on e-Learning.

Weber, G., Brusilovsky, P. (2001). tELM-ART: an adaptive versatile system for web-based instruction. International Journal of Artificial Intelligence in Education, 12, 351-384.

Weber, G., Specht, M. (1997) User modeling and adaptive navigation support in www-based tutoring systems. In: Jameson, A., Paris, C., Tasso, C. (Eds.), User Modeling: Proceedings of the Sixth International Conference. Vienna, New York, Springer Wien New York, 289-300.

V. Drąsutė received her master degree in informatics engineering (programme of programe's systems engineering) from Kaunas University of Technology in 2007. Now she is a $\mathrm{PhD}$ student of informatics engineering and major coordinator at the Department of Multimedia Engineering, Faculty of Informatics, Kaunas University of Technology, Lithuania. Her research interests include rationalization methods and provision of elearning syllabus and methodical material, also learning technologies, management and structure of e-learning systems, interactive e-learning environments, application of intelligent techniques and systems, software engineering. She is a coordinator and researcher in national and international projects and author or co-author of 18 research papers.

S. Drasutis received his doctoral degree in informatics engineering in Kaunas University of Technology in 2006, now holds the position of a lecturer in the Department of Multimedia Engineering, Faculty of Informatics, Kaunas University of Technology, Lithuania. His current research interests are in distance and e-learning systems, multimedia engineering and web development. He is a researcher in several international projects and author or co-author of 10 research papers.

D. Baziukè received her master degree in mathematics (numerical analysis and systems) from Klaipeda University in 2002 and doctoral degree in informatics from Vytautas Magnus University (Kaunas) and Institute of Mathematics and Informatics (Vilnius) in 2007. Now she is assoc. professor in the Department of Computer Science, Klaipeda University and director of Distance and E-Learning Centre at Klaipeda University, conducting the work flow and activity related to distance and e-learning, participating in formation of policy according new developments establishing and supporting flexible study forms. Her research is focused on adaptability, intelligence, and decision making processes in virtual learning environments, machine learning algorithms with various applications, and data mining. She is an author or co-author of more than 20 research papers. 


\title{
Metodas racionaliam mokomosios medžiagos pateikimui
}

\author{
Vida DRĄSUTĖ, Sigitas DRĄSUTIS, Dalia BAZIUKĖ
}

Nuotoliniame ir el. švietime dèka technologijų taikymo ir spartaus technologijų vystymosi, ugdymo procesas yra praturtintas ịvairiu mokslo sričiu pasiekimais. Šis techno-edukacinis šuolis ivvyko praejjusio dešimtmečio eigoje. Virtualusis mokymas(is) tampa vis populiaresnis kaip naujas mokymosi būdas, sukuriantis prielaidas studijoms patogiu laiku ir vietoje naudojant specialiai parengtą mokymo medžiagą. Technologiju pažanga sąlygoja ir vartotojų poreikių augimą. Pastaroji taip pat ịkvepia lanksčiu, bet kokybišku, ugdymo ir mokymosi būdu paieškai. Vienas tokių būdụ yra išmaniai prisitaikančios mokymo(si) aplinkos, kurios pamažu turètų tapti ịprastu ịrankiu virtualiam mokymui(si) teikti.

Straipsnyje analizuojamos adaptyvios mokymosi aplinkos (AMA), jų galimybès, agentai ir ju elgesys tokiose sistemose. Aprašomas semantinio indeksavimo algoritmu grindžiamas racionalaus mokymo(si) medžiagos pateikimo pagal studento žiniu lygi, o dèstytojui atnaujinti mokymo turini atsižvelgiant ị besimokančiuju mokymosi rezultatus, metodas. Tai dar vienas mokytojo/dèstytojo ịrankis. Pristatomi tyrimo, atlikto pritaikant pasiūlytą metoda, rezultatai. 